\title{
Engineering Students' Academic and on-the-Job Training Performance Appraisal Analysis
}

\author{
Jake M. Laguador
}

\begin{abstract}
This study determined the level of academic performance and OJT performance based on the assessment of immediate superiors of $\mathbf{2 3 3}$ engineering student-trainees from Lyceum of the Philippines University (LPU) in Batangas City. This research utilized the quantitative descriptive as well as qualitative methods of research and data were collected using documentary analysis of computed grades and comments from the employers. LPU Engineering students as observed by their immediate superiors were courteous, honest, have good moral character, with self-efficacy, good in oral communication, patient and positive thinkers. Mechanical engineering students who performed well in their assigned task during their OJTs also obtained notable ratings in general and professional education courses. It is contrary to the finding that the performance of Industrial Engineering students who obtained higher academic ratings have lower job performance. The researcher formulated an Internship manual that would serve as a guide for the training of the students in the four engineering programs of LPU.
\end{abstract}

Index Terms-Academic performance, engineering, internship, on-the-job training.

\section{INTRODUCTION}

Learning takes place in different avenues and forms of human existence. Formal education from academic institutions is basically the proper venue for acquiring appropriate knowledge and skills necessary for future employment. On-the-job training (OJT) is part of the tertiary curriculum which connects the gap between theory and practice as well as between classroom education and real industry life presenting a more precious learning experience that improves the importance of the academic program and form the view of personal and social usefulness [1]. Allowing the graduating students to apply what they have learned from books in a work environment would develop their work values and attitude necessary to achieve the ultimate goal of education to produce efficient and effective leaders and professionals in cross-cultural and multidisciplinary undertakings.

The objectives of internship are to create an opportunity to learn about a profession; and to generate values as well as substance in skills for students [2], [3]. It is a part-time job for specific period, paid modestly or unpaid, in which the interns gain knowledge while contributing to the organization. It provides students an understanding of a real business situation, but with supervision and support [1]. It is a popular method of experiential learning where students come face to

Manuscript received April 11, 2013; revised June 21, 2013. This work was funded by the Lyceum of the Philippines University-Batangas City, Philippines.

J. M. Laguador is with the College of Engineering in Lyceum of the Philippines University, Philippines (e-mail: jakelaguador@yahoo.com). face with the real world of work and its complexities, something that cannot be replicated in the four walls of the classroom [4].

Today, most industries are providing opportunities for the engineering students to have hands-on training for future employment because they realize that the training of engineers is not the sole responsibility of the academe but a shared task with industry. Training aims to change trainees' performance through improved knowledge, skills, and attitude [5].

Several industries have shared generously their company resources to impart knowledge, skills and also work values to the on-the-job trainees of the College of Engineering in LPU for the past several years. The training and experiences brought by the companies to the students have contributed to the development of their attributes to become true engineers and professionals in the real work environment even for a brief period of one semester or equivalent to 600 hours.

Among all potential interactive linkages, companies can directly cooperate with or acquire research results from academic institutions, financially support academic research, and hire students, graduates, and researchers etc. to enrich their innovation capabilities.

This study determined the students' level of academic performance and their OJT performance in terms of personal characteristics, attitudes towards job, job performance, adherence to company policies and as well as their competence based on the assessment of immediate superiors of engineering student-trainees who are now graduates of Computer Engineering, Electronics Engineering, Industrial Engineering and Mechanical Engineering programs at LPU. This will help determine the required attitude that the students should possess when they get employed after graduation. Determining the academic performance of engineering graduates in terms of their final grades in General Education and Professional Education Courses would also provide basis for clear understanding of their performance at work and at school. Analyzing the significant relationship between OJT performance and the academic performance of the engineering graduates in terms of General Education and Professional Education Courses would identify the importance of theories and knowledge learned from the university which should be applied through practice in the actual work place. Differences in the OJT performance when the students were grouped according to their respective programs were also investigated.

\section{METHODS}

\section{A. Design}

This research utilized the quantitative descriptive and qualitative methods of research. Documentary analysis was 
used to gather and quantify the data and information on appraisal report and academic performance based from the students' final grades in general and professional courses from $1^{\text {st }}$ year to $5^{\text {th }}$ year. The researcher documented the comments and observations given to the engineering trainees from their immediate superiors/evaluators during OJT and qualitatively interpreted and compared the results of annotations among four engineering programs under study.

\section{B. Participants}

The study included the performance appraisal report of 233 engineering students who were enrolled in their OJT from 2006 to 2010. BS Computer Engineering (BSCoE), BS Industrial Engineering (BSIE), BS Mechanical Engineering (BSME) and BS Electronics Engineering (BSECE) students were the included programs in the study.

TABLE I: DISTRIBUTION OF RESPONDENTS ACCORDING TO THEIR RESPECTIVE DEGREE PROGRAMS

\begin{tabular}{lccc}
\hline \multirow{2}{*}{ Programs } & \multicolumn{2}{c}{ Frequency } & Actual Subjects \\
\cline { 2 - 4 } & Total & Actual & \% \\
\hline BSECE & 45 & 45 & 100 \\
BSIE & 44 & 40 & 91 \\
BSME & 26 & 15 & 58 \\
BSCoE & 144 & 133 & 92 \\
\hline Total & $\mathbf{2 5 9}$ & $\mathbf{2 3 3}$ & $\mathbf{9 0}$ \\
\hline
\end{tabular}

Out of 259 graduates of four engineering programs, only two hundred thirty - three (233) OJT appraisal reports were retrieved from the records of the College of Engineering which comprised of 90 percent of the actual subjects under study.

\section{Instrument}

The instrument used in the study has been validated by the Department Chairmen of four engineering programs and this instrument has been utilized by the College of Engineering for almost ten years in assessing the performance of its trainees. The student office trainee performance appraisal report is being rated by the immediate superiors of the On-the-Job Trainees after their 600 - hours of training.

\section{Data Gathering Procedure}

The data were collected using documentary analysis of the submitted and compiled OJT Performance Appraisal Report rated by the immediate superiors of the engineering trainees. The academic performance ratings of the students were obtained from the compiled grade sheets and report cards of students under study from the College of Engineering.

\section{E. Data Analysis}

The data were collected, classified, tabulated and coded for analysis. Frequency count and percentage were used to describe the frequency distribution of the OJTs. Weighted Mean and Rank were used to determine the level of OJT performance and academic performance of engineering students. Pearson - Product Moment Correlation Coefficient was used to test the significant relationship between the OJT performance and the academic performance of the engineering students. Analysis of Variance was used to test the significant difference in the OJT performance when the students were grouped according to their respective programs.

\section{RESUlTS AND DisCUSSION}

Most of the Electronics Engineering students conducted their OJTs in Telecommunication Service Providers and Semiconductor companies. These types of companies that provide communication services are also best training grounds with facilities and work environment that are good sources of information related to electronics. They could also provide enough skills and experiences in handling problems related to their fields of specialization. Some of the training companies where electronics engineering students conducted their OJTs are automobile and automotive wiring harness manufacturers. Based on the information gathered, they were assigned in the Management Information System (MIS) department to monitor the Network communication system of the companies.

Electronics manufacturing industries provide the knowledge and expertise to BSECE and BSCoE students in terms of their company operations, processes and other related activities to electronics and communication technologies. The students were trained to operate large machines used to manufacture components designed for certain electronic gadgets and devices.

Hardware and Software distributors and Software/ Information Technology Solution Providers were also types of companies where most Computer Engineering students conducted their OJT. They were given the chance to know the flow and process of handling the business of product distribution and providing software solutions to the clients. The operation of these establishments provides entrepreneurial skills to the students on how to deal with the customers and also learning the marketing aspects of Computer and Information Technology.

Mechanical and Industrial Engineering students had chosen to work at Power Generation and Energy Related Business, Milling Industries and Steel Fabrication. These companies offered products or services most related to Mechanical and Industrial processes. Results show that majority of the students have chosen the right companies to become their training grounds during OJT.

Majority of the companies of 106 BS Computer Engineering students belong to Private sector against 11 or 18 percent of government agencies while 100 percent for BS Electronics Engineering are Private companies. Forty-five or 97.8 percent of the Industrial Engineering students took their OJTs in Private companies while only one BSIE student decided to take the OJT in Government agency while 13 or 86.7 percent of the BSME students went to Private companies while two BSME students or 15 percent in Government agencies. Government Agencies are also adapting the electronics and computer technologies. They keep on updating their system or service being provided to the community, so they need people or human resources who are knowledgeable on these fields. Private establishments offered more opportunities for trainings in the field of engineering compared to government agencies in the case of the Philippines. Private sectors have enough facilities, equipment and work environment for the production of goods and services for the consumers and end-users, although government agencies also have the capability to train engineering students on their respective fields of endeavor but with limited possibilities. 
Workplace leaders have an insatiable expectation for their staff to deliver consistently pristine performance [6], therefore, trainees must demonstrate abilities that would satisfy the expectations of their immediate superiors. On-the-Job Trainees learned to work with proper guidance towards the achievement of appropriate behavior. LPU Engineering students as observed by immediate superiors are courteous, honest; possess good moral character, with self-efficacy, good in oral communication, patient and positive thinkers. They accept assigned job or task without hesitation, they possess positive attitude towards work, they have sense of humor, cheerful, helpful, team player, and diligent with admirable work ethics. Therefore, team-related and communication skills should be practiced throughout technical courses [w].

In terms of the over-all OJT performance, BS Electronics Engineering students obtained the highest performance among the four engineering programs followed by BS Computer Engineering and BS Mechanical Engineering while BS Industrial Engineering students obtained the lowest rating. BSECE students demonstrate the ability to impress their immediate superiors with great attitude towards job, carrying out tasks exceeding the expectations of their bosses and notable respect and diligence to follow the rules and regulations of the company being served with the desire of doing things best for the first time and doing more things to excel.

Immediate superiors still observed the need to train the computer engineering students to diagnose the problems of the computer, how to install hardware and software and the maintenance of the entire system. Evaluators noticed that Engineering students during their trainings have willingness to learn new skills and possessed the interest to perform tasks related to these skills. Engineering students are also friendly and easily fit to the group; they are responsible with self-confidence, tidy and presentable, possessed leadership skills, hardworking, and trustworthy individuals.

The evaluators provided several comments for the improvement of the students that needed to be addressed directly to the persons responsible in the College of Engineering to further enhance or strengthen its program offering to develop more the students' knowledge, skills, work values and attitude to competently prepare them in dealing and handling with people and responsibilities in various work settings.

The academic performance of the Engineering students shows that curriculum plays a vital role on the delivery of appropriate instruction to ensure the quality of knowledge, skills and values as possible outcomes of learning process being undertaken by the university.

College of Engineering must take necessary skills for the improvement of the students' behavior towards the achievement of right competency through increasing the level of study habits and academic performance.

The BSECE and BSME students obtained the highest percentages in General Education courses which show that they are intellectually fit and qualified to take board programs while and BSIE students obtained the highest percentage in Professional Education courses due to its nature of study different from board programs like BSME and SBECE. The low equivalent percentage weighted mean of BSME couldn't be considered for their low performance or lack of study habits. It is just happened that the nature of the program is more complicated than other engineering programs in LPU plus the strict rules, regulations and high standard of their major course professors added up to their very challenging set-up.

Table II shows the relationship of the OJT performance to the General and Professional Education Ratings for $\mathrm{CoE}$, ECE, IE and ME students. The general education courses include Languages, Social Sciences, Physical and Natural Sciences.

TABLE II: DISTRIBUTION OF RESPONDENTS ACCORDING TO THEIR RESPECTIVE DEGREE PROGRAMS

\begin{tabular}{|c|c|c|c|c|c|c|}
\hline \multirow{2}{*}{$\begin{array}{l}\text { OJT } \\
\text { Criteria }\end{array}$} & \multirow{2}{*}{ Crs } & \multirow{2}{*}{ Value } & \multicolumn{4}{|c|}{ Programs } \\
\hline & & & CoE & ECE & IE & ME \\
\hline \multirow{4}{*}{$\begin{array}{l}\text { Personal } \\
\text { Characteristics }\end{array}$} & \multirow{2}{*}{ Gen. } & r-value & -0.017 & -0.046 & -0.280 & 0.383 \\
\hline & & Sig & .974 & .250 & .080 & .054 \\
\hline & \multirow{2}{*}{ Prof. } & r-value & 0.029 & 0.056 & -0.331 & 0.152 \\
\hline & & Sig & .944 & .719 & $.037 *$ & .464 \\
\hline \multirow{4}{*}{$\begin{array}{l}\text { Attitude } \\
\text { Towards the } \\
\text { Job }\end{array}$} & \multirow{2}{*}{ Gen. } & r-value & 0.036 & -0.054 & -0.271 & 0.543 \\
\hline & & Sig & .353 & .126 & .091 & $.004 * *$ \\
\hline & \multirow{2}{*}{ Prof. } & r-value & -0.030 & 0.022 & -0.390 & 0.406 \\
\hline & & Sig & .859 & .636 & $.013 *$ & $.040 *$ \\
\hline \multirow{4}{*}{$\begin{array}{l}\text { Job } \\
\text { Performance }\end{array}$} & \multirow{2}{*}{ Gen. } & r-value & 0.041 & -0.075 & -0.422 & 0.392 \\
\hline & & Sig & .142 & .856 & $.007 * *$ & $.047 *$ \\
\hline & \multirow{2}{*}{ Prof. } & r-value & -0.118 & 0.106 & -0.483 & 0.205 \\
\hline & & Sig & .211 & .222 & $.002 * *$ & .320 \\
\hline \multirow{4}{*}{$\begin{array}{l}\text { Adherence to } \\
\text { Company } \\
\text { Policies }\end{array}$} & \multirow{2}{*}{ Gen. } & r-value & 0.044 & -0.202 & -0.094 & 0.419 \\
\hline & & Sig & .308 & .827 & .561 & $.034 *$ \\
\hline & \multirow{2}{*}{ Prof. } & r-value & 0.173 & -0.019 & -0.273 & 0.329 \\
\hline & & Sig & .190 & .052 & .090 & .100 \\
\hline \multirow{4}{*}{ Competencies } & \multirow{2}{*}{ Gen. } & r-value & -0.027 & -0.111 & -0.313 & 0.246 \\
\hline & & Sig & .997 & .803 & .051 & .233 \\
\hline & \multirow{2}{*}{ Prof. } & r-value & -0.090 & 0.075 & -0.330 & 0.143 \\
\hline & & Sig & .745 & .410 & $.039 *$ & .480 \\
\hline
\end{tabular}

The significant relationship test result revealed that final ratings in General and Professional Education courses of BSCoE and BSECE had nothing to do with their OJT performance. This means that students with higher grades can either obtain high or low OJT performance and those students with lower grades can possibly obtain the same.

The positive relationship of test result computed for ME signifies direct association of their performance in academics and OJT. Majority of ME students who obtained high grades in Professional Courses have better performance in attitude towards work than those students with low grades. Other OJT variables are not significantly related to their professional courses. This means that no matter how high or low their grades from professional courses have nothing to do with their Personal Characteristics, Job Performance, Adherence to Company Policies and Competencies.

ME students who performed well in their assigned task during their OJTs also obtained significantly higher ratings in general and professional education courses. It is contrary to the finding that the performance of IE students who obtained higher academic ratings has lower job performance. 
Industrial engineering students with low academic grades demonstrate great extent in job performance than IE students with better grades in general and professional education courses.

Other factors or reasons might cause the negative association of the results for Industrial Engineering students but it is another research endeavor to work with some intervening variables.

TABLE III: DIFFERENCE IN THE OJT PERFORMANCE WHEN THE STUDENTS WERE GROUPED ACCORDING TO PROGRAMS

\begin{tabular}{lccc}
\hline OJT Criteria & F-value & Sig. & Remarks \\
\hline 1. Personal Characteristics & 4.412 & .005 & Significant \\
2. Attitude Towards the Job & 4.689 & .003 & Significant \\
3. Job Performance & 5.095 & .002 & Significant \\
4. Adherence to Company Policies & 2.885 & .036 & Significant \\
5. Competencies & 10.273 & .000 & Significant \\
\hline
\end{tabular}

The four groups of engineering students have significant differences in their OJT performances due to the different levels of their capacity to think, behave and apply what they have learned, achieved and experienced which affect their work performance. The significant differences exist between the performance of Electronics Engineering and Industrial Engineering programs which confirmed that the OJT performance of BSECE is significantly higher than the BSIE performance in terms of Personal Characteristics and Adherence to Company Policy.

Based on the findings of the study, the researcher formulated an Internship manual that would serve as a guide for the training of the students in the four engineering programs of LPU. Seminars and workshops that aim to develop the students' confidence, work values and necessary skills will also be offered to the engineering students to prepare them adequately for their on-the-job training.

\section{CONCLUSION}

Company linkages must be strengthened through participating in different professional organizations where numerous manufacturing industries are also members and involved in the activities of the association. Orientation, seminars and workshop would be taken in place before the engineering students joined the group of professional employees with the objective of increasing their level of awareness and confidence regarding what they must expect to others and what might others would expect of them just to give them an image of what they would become inside the companies. A strong desire and commitment at college and department level for meaningful and fruitful internship to help college to achieve its goal and Interns to acquire skills [7]. Engineering students must not only be kept informed and oriented regarding the significance of their grades in college for their future employment but the department must also focus in teaching the students through classroom interaction on valuing the process of how they learned or discovered to become productive and responsible individual through maintaining high grades or in the case of engineering even obtaining passing grades are very much important.

Help the students realize through attending seminars or inviting qualified speakers during general assembly or college days the benefit of having positive mental attitude that would provide them a source of reflection. This could somehow change their views in life to increase their level of study habits and be more active and cooperative individual while working in a team that they may use towards the productivity of their future employment.

Engineering students are grouped according to their individual similarities with usual differences and each group must be given enough attention to address their individual needs based on their capabilities. Not all seminars might be useful to all engineering students, but it is suggested to implement a program design that would develop what is missing to the skills and values of the specific students to make this undertaking worthwhile. Improvement of communication skills and interactions with others [8] would provide a better opportunity for the students to gain confidence in the workplace. Companies are very much willing to share the knowledge of their employees to the trainees. The implementation of a well-planned job description that involves high level of on-the-job knowledge sharing equally proves to the employees that the organization is giving importance to knowledge sharing [9]. The internship should be flexible and modified to the needs of both the student and the host organization and it should be planned so that the student is given the chance to narrow the gap between theory and practice [1]. Leaders in government and industries have been called for new graduates to mastery the employability skills such as communication skills, teamwork, problem solving and decision making skills [10]. Therefore, before the graduates enter the workforce, academic institutions must ensure that these skills are already acquired by the students from formal instruction and internship programs.

The OJT Manual must be reviewed yearly to update the material and make it appropriate to the currents processes of the university and needs of the industry partners.

\section{REFERENCES}

[1] Z. Batool, N. Ellahi, and A. Masood, "National Internship Programmes and its Evaluation: A Case Study of Punjab Region," Academic Research International, March 2012.

[2] J. E. Beck and H. Halim, "Undergraduate Internships in Accounting: What and How Do Singapore Interns Learn from Experience?" Accounting Education: An International Journal, vol. 17, no. 2, pp.151-172, 2008.

[3] L. Y. Pei, D. Daud, and K. R. Jonathan, "Perceptions of Logistics Students on Internship Programme: The Case of Private Higher Institution in Malaysia," Canadian Social Science. vol. 8, no. 4, pp. 1-7, 2012.

[4] T. Warinda, "Accounting Students' Evaluation of Internship Experiences from a Skills Perspective," International Journal of Asian Social Science. vol. 3, no. 3, pp, 783-799, 2013.

[5] M. J. Hoque and K. Usami, "Effects of Agricultural Extension Workers' Perceptions of Off-the-Job Training and On-the-Job Training to the Development of Their Skills," American Journal of Agricultural and Biological Sciences, vol. 2, no. 3, pp. 184-190, 2007.

[6] G. Procknow, "Issues with transferring knowledge acquired through workplace pedagogical interventions to on-the-job application," International Journal of Research Studies in Management, vol. 1, no. 1, pp. 31-38, April 2012.

[7] B. S. Bhavsar. (July- December, 2010). Internship Training. Healthline. [Online]. 1(1). pp. 3-4, Available: http://iapsmgc.org/healthlineeditorial.pdf.

[8] S. Goh, W. Coaker, and D. Thorpe, "How engineers become CEOs: implications for education and training," Journal of Achievements in Materials and Manufacturing Engineering, vol. 31, no. 2, pp. 846 852, December, 2008. 
[9] N. N. A. Mansor and T. Peariasamy, "On-the-job knowledge sharing: how to train employees to share job knowledge," Jurnal Kemanusiaan, vol. 12, pp. 97, Dec. 2008.

[10] Y. Yusoff1, M. Z. Omar, A. Zaharim, A. Mohamed, and N. Muhamad, "Employability Skills Performance Score for Fresh Engineering Graduates in Malaysian Industry," Asian Social Science. vol. 8, no. 16, p. 140-145, 2012.

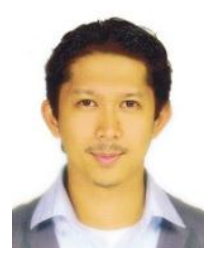

Jake M. Laguador is a professor at the College of Engineering in Lyceum of the Philippines University (LPU) - Batangas. He is a baccalaureate degree holder in Computer Engineering, Master's Degree holder in Public Administration and Doctorate Degree in Educational Management. He works as Faculty Researcher in Engineering, Maritime and Business Professions. His fields of research interest are
Educational Psychology, Engineering and Computer Education, Graduates Employability and Information Technology. At present, he is a member of International Economics Development Research Center (IEDRC), International Association of Computer Science and Information Technology (IACSIT), Network of CALABARZON Educational Institutions (NOCEI), CALABARZON Research Council (CRC), and Institute of Computer Engineers of the Philippines (ICpEP). 